\title{
The influence of lactation stage on the milk constituents of Sahelian goats
}

\author{
J.A Tbeawuchi, F.O. Ahamefule, and I.A Ringim ${ }^{2}$ \\ 'Department of Ruminant Animal Production, Afichael (Okpara liniversity of Agriculture. Umudike
${ }^{2}$ Depariment of Animal Science, Linversity of Alaiduguri, Nigeria
}

\begin{abstract}
Twehe lacrating sahclian goats aged between 2 and 3 wears and averaging $25 \mathrm{~kg}$ body weight were selected from the herd at the University of Aaidiguri 7eaching and Research farm, for a 19- week lactation stutiv. The does were classified tnto earlv: mid, and late lactation stages and maintained daily on $1 \mathrm{~kg}$ concentrate mixture per animal in addition to grazing on Gamba grass. Milk collected were analysed for total wolicls (TS), butterfot, protein, solids -not-fat (SNF), Ash and energy. The mean percentage values $(M+S F)$ of colostrum were $\mathrm{SS} / 4.96 \cdot 0 \mathrm{Al}$; buterfat $8.58+1.00$; protein $5.64 \pm 0.31 ;$ ash $0.93+0.07 ; . S N F 6.37 \pm 0.51 ;$ and energy $3.21+0.39 \mathrm{MJ} / \mathrm{kg}$. The overall mean values for mature milk were 13.15-0.27, 7.52.0.18, $+.81 \pm 0.14,0.76+0.03,5.66+0.16 \% 6$ and 2.7910 .12 MU $K G$ respectivelv for $T S$. fat, protein, ash SVI and energ: There was a gradual decline in the values of all the components of colostrum from day 1- 6 after kidding. Generally, colostrum constituents were higher in concentration than thase of mature mith on the $7^{\text {th }}$ day affer parturition. The mature milk constituents were significantly affected (P 0.05$)$ by stage of lactation. These constituents tended to uncrease with achancing lactation. Milk constituents (especially Fat, protein and $S(F)$, as evident from thus study could be manipulated throtigh feeding.
\end{abstract}

Key Words: Sahctian goats, lactation stage. milk composition.

\section{Introduction.}

In Nigeria. cattle have bcen the traditional source of milk for human consumption. The indigenous cattle breeds have continued to dominate the traditional livestock subsector despite the fact that their genetic merit for milk production has consistently fallen far short of demand especially in the urban centres. The deficit has been met by importation of milk and milk products over the years.

There is a noed to explore other sources of milk if the country is to attain self-sufficiency in dairy production and be able to satisfy the protein needs of a rapidly expanding population. With population of goats estimated at 40 million (F.O S. 1996) The country is better placed to realize significant contribution to the dairy industry from goats. Moreso, there is now a growing awareness of the unique differences between goat and cow milk for human mutrition and health (Parkash and Jenness. 1968: Devendra and Burns. 1970; Nuru, 1990). Goat milk is more casily digested than cow milk due to the fact that the fat is fincr and more easily assimilated. In addition, goat milk is particularly rich in antibodies and low in bacterial count especially when freshly drawn (Belanger, 1975). It is partly due to these biomedical values that goat milk is usually prescribed in treatment of many human ailments(French, 1970: Haenlcin,1981), Goat milk varies in composition at different stages of location and this is of nutritional importance to the young goat. The composition of goat milk in 


\section{Ibeawuchi, Ahamefule and Ringim}

temperate countries has been extensively investigated and reviewed (Parkash and Jenness, 1968; Jenness and Sloar, 1970; Jenness, 1980; Haelein, 1981). With the exception of some studies on the milk production and composition of the Red Sokoto and the West African Dwarf breeds in Nigeria (Malau-Aduli and Anlade, 2001; Malau-Adule et $a l, 2000$; James and Osinowo, 2000). It appears that little attention has been given to the evaluation of milk of other breeds.

The present study therefore reports on the chemical composition of the milk from Sahelian goats as influenced by stage of lactation.

\section{Materials And methods}

Animals and their management

Twelve Sahelian does, the Borno White variety of between 2 and 3 years old, averaging $25 \mathrm{~kg}$ weight were selected from the goat unit of the University of Maiduguri Teaching and Research Farm for the lactation studies that lasted for a 19-week period. The animals were confined in individual pens and provided with fresh clean water and salt licks ad libitum. They were turned to pasture composed mainly of Gamba (Andropogon gayanus) from $08.00 \mathrm{GMT}$ to I2.00 GMT daily. In addition to grazing, the does received $1 \mathrm{~kg}$ concentrate mixture per head daily. The proximate compositions of the grazed forage and concentrate are as shown in Table 1.

Table 1 Ingredients and nutrients compositions of the concentrate and grazed forage.

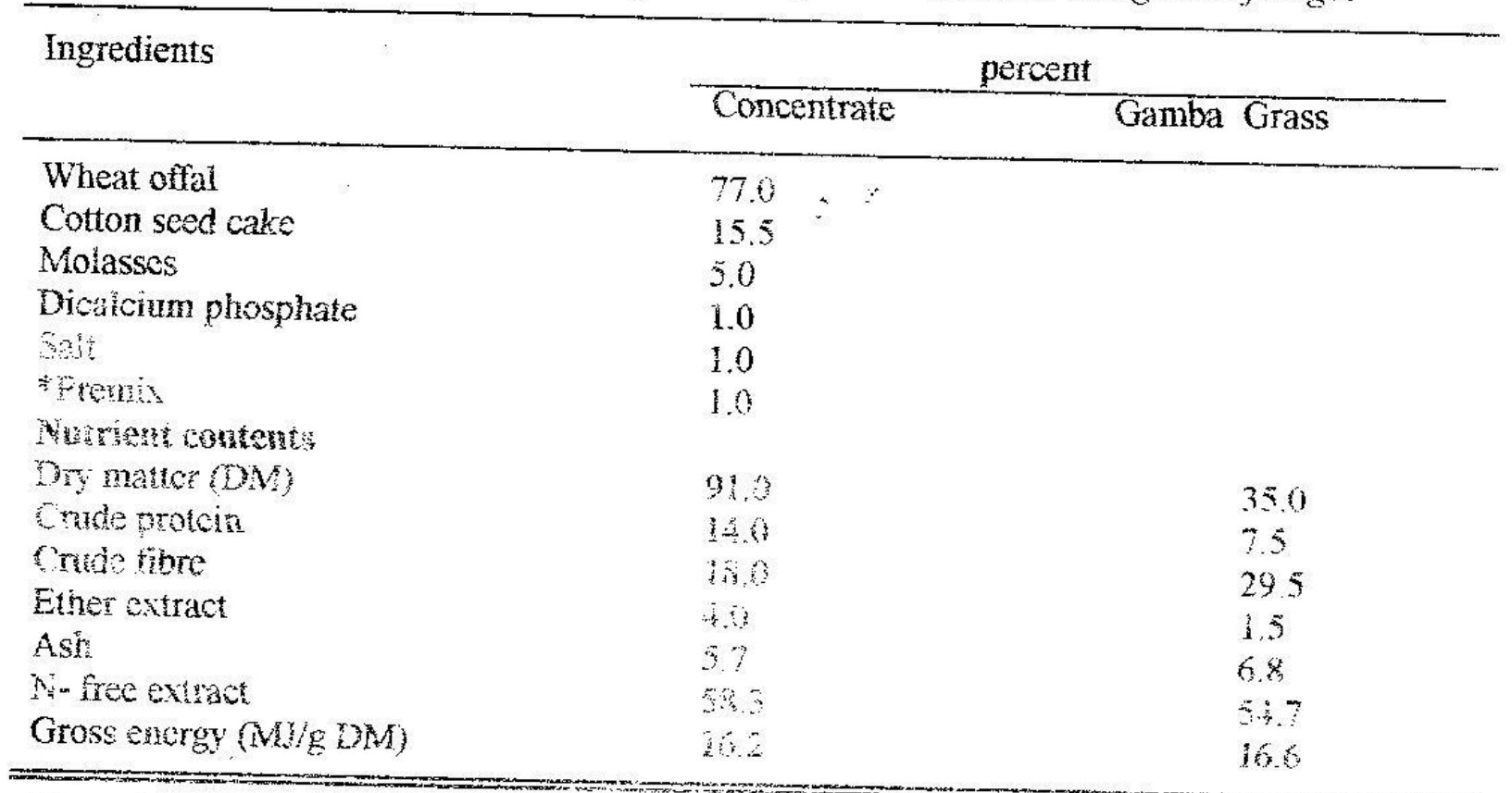

*Toprovide the following per ly

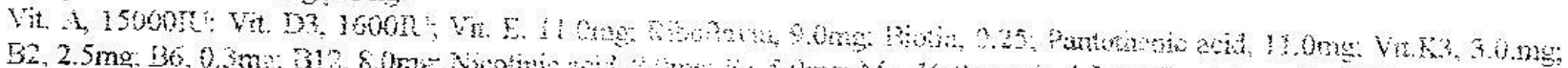

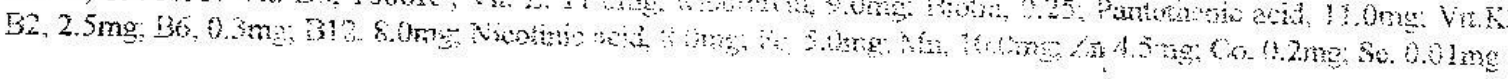

The goats were clessich acordirg to stre of lactation. Frior to kidung each gravid dow vos inmedately contind to he kidding pen and fol gambi hay snd anter partrition, the krds remained with the dam for a wed before ghiss the herd. Weaning periods varied from is 5 months,

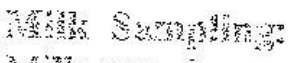

Min sonples were obtained wokly from each

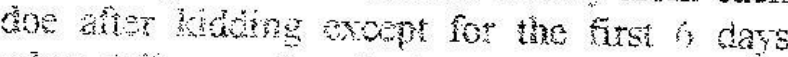
when daly sumpiss of colostnum were collecied. Abont tom of min or colostrum was owamed

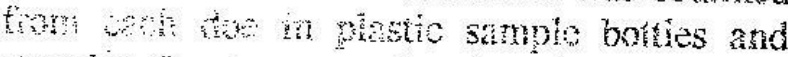

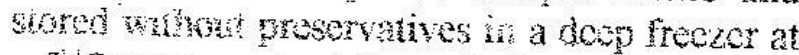
-5 . mon recuite for analysis. 
Analytical procedures.

The colostrum and mature milk samples were analysed in triplicates for total solids, protein $(\mathrm{N}$ $X$ 6.38), Fat, Solids-Not-Fat, total ash and energy. Total solids was determined by drying $5 \mathrm{~g}$ sample to constant weight at $105^{\circ} \mathrm{C}$ for 24 hours. Fat was extracted by the Roese-Gottlieb cold extraction method (Pearson, 1977). Solidsnot-fat was determined as the difference between total solids and fat. Crude protein and total ash were determined by the A.O.A.C (1990) procedures. Milk energy (Y MJ/kg) was estimated using the multiple regression equation (MAFF, 1977);

$\mathrm{Y}=0.386 \mathrm{~F}+0.0205 \mathrm{SNF}-0.2336$ where $\mathrm{F}$ and SNF are percentage values of fat and solids-notfat. Statistical cvaluations were made using the completely randomized design according to steel and Torrie (1980)

\section{Results and discussion}

The results obtained for the gross composition of colostrum from day 1-6 after parturition are summerised in Table 2.

Table 2 Composition of Colostrum of Sahelian goats

\begin{tabular}{lcccrrrrr}
\hline & \multicolumn{1}{c}{ Days After Kidding } \\
\cline { 2 - 10 } Components & 1 & 2 & 3 & 4 & 5 & 6 & Mean & SE \\
\hline Total solids (\%) & 19.90 & 17.30 & 14.88 & 14.60 & 11.79 & 10.81 & 14.96 & 0.41 \\
Fat (\%) & 12.40 & 10.70 & 7.80 & 7.80 & 6.20 & 6.60 & 8.58 & 1.00 \\
Protein & & & & & & & & \\
(NX6.38) (\%) & 6.30 & 6.09 & 6.08 & 6.02 & 4.98 & 4.39 & 5.64 & 0.31 \\
Solid-not-fat (\%) & 7.50 & 7.11 & 7.05 & 6.80 & 5.58 & 4.20 & 6.37 & 0.51 \\
Ash (\%) & 1.20 & 1.00 & 0.98 & 0.80 & 0.79 & 0.80 & 0.93 & 0.07 \\
Energy (MJ/kg) & 4.70 & 4.04 & 2.93 & 2.91 & 2.28 & 2.40 & 3.21 & 0.39 \\
\hline
\end{tabular}

The mean values of total solids (TS), Fat, Protein, solids-not-fat (SNF), ash and energy were $14.96+0.41$. $8.58+1.00, \quad 5.64+0.31$, $6.37+0.51,0.93+0.07$ and $3.21+0.39 \mathrm{MJ} / \mathrm{kg}$ respectively. There was a gradual decline in the percentage values of these constituents of colostrum from the first to the sixth day after kidding. The composition of colostrum approached that of mature milk on the seventh day of kidding. Several workers have reported similar trend in the composition of colostrum of goat $\mathrm{Mba}$ et al; 1975; Akinsoyinu and Akinyele, (1979), cows (Rock, 1976: Akinsoyinu, 1981) and other species (Jenness and sloan, 1970).

The composition of mature milk with advancing lactation is presented in Table 3. 
Ibeawuchi, Ahamefule and Ringim

Table 3: Components of mature milk of sahelian goats at different stages of lactation.

\begin{tabular}{|c|c|c|c|c|c|c|c|}
\hline \multirow{2}{*}{\multicolumn{3}{|c|}{$\begin{array}{l}\text { LACTATION } \\
\text { STAGE WEEKSTS }\end{array}$}} & \multicolumn{4}{|c|}{ Components (\%) } & \multirow{3}{*}{$\frac{\frac{\text { Energy }}{(\mathrm{MJ} / \mathrm{Kg})}}{2.07}$} \\
\hline & & & \multirow{2}{*}{$\frac{\text { FAT }}{5.71}$} & \multirow{2}{*}{$\begin{array}{l}\text { Protein } \\
4,43\end{array}$} & \multirow{2}{*}{$\frac{\text { Ash }}{0.60}$} & \multirow{2}{*}{$\frac{\text { SNF }}{5.00}$} & \\
\hline & 2 & 10.71 & & & & & \\
\hline EARLY & 3 & 11.72 & 6.83 & 4.30 & 0.58 & 4.89 & 2.50 \\
\hline & 4 & 11.24 & 6.40 & 4.26 & 0.56 & 4.84 & 2.33 \\
\hline & 5 & 12.97 & 7.03 & 4.27 & 0.69 & 4.94 & 2.58 \\
\hline & 6 & 11.29 & 7.47 & 5.10 & 0.70 & 5.80 & 2.75 \\
\hline & 7 & 13.30 & 7.40 & 5.10 & 0.77 & 5.90 & 2.74 \\
\hline Mean & & $11.87^{a}$ & $6.81^{2}$ & $4.41^{\circ}$ & $0.65^{\prime \prime}$ & $5.07^{a}$ & $2.49^{a}$ \\
\hline SE & & 0.36 & 0.23 & 0.41 & 0.03 & 0.17 & 2.11 \\
\hline \multirow{6}{*}{ MID } & 8 & 12.51 & 7.47 & 4.31 & 0.71 & 5.84 & 2.77 \\
\hline & 9 & 12,80 & 7.38 & 4.72 & 0.70 & 5.42 & 2.73 \\
\hline & 10 & 13.53 & 8.67 & 4.10 & 0.68 & 4.86 & 3.21 \\
\hline & 11 & 13.74 & 8.44 & 4.48 & 0.80 & 5.30 & 3.13 \\
\hline & 12 & 14.53 & 8.61 & 5.10 & 0.99 & 5.92 & 3.21 \\
\hline & 13 & 14.26 & 8.51 & 4.97 & 0.80 & 5.77 & 3.16 \\
\hline Mean & & $13.56^{b}$ & $8.18^{\circ}$ & $4.61^{\mathrm{a}}$ & $0.76^{b}$ & $3.32^{11}$ & $3.04^{\circ}$ \\
\hline SE & & 0.32 & 0.24 & 0.16 & 0.02 & 0.17 & 0.09 \\
\hline \multirow{6}{*}{ LATE } & 14 & 13.60 & 7.33 & 5,45 & 0.80 & 6.27 & 2.72 \\
\hline & 15 & 13.66 & 7.14 & 5.72 & 0.80 & 6.52 & 2.66 \\
\hline & 16 & 13.83 & 7.65 & 5.36 & 0.84 & 6.18 & 2.84 \\
\hline & 17 & 14.37 & 8.08 & 5.36 & 0.94 & 6.29 & 3.01 \\
\hline & 18 & 14.67 & 7.83 & 5.94 & 0.89 & 6.84 & 2.92 \\
\hline & 19 & 15.50 & 7.37 & 6.14 & 0.98 & 7.13 & 2.75 \\
\hline \multirow{4}{*}{\multicolumn{2}{|c|}{$\begin{array}{l}\text { Mean } \\
\text { SE } \\
\text { Overall Mean } \\
\text { SE }\end{array}$}} & $14.303^{b}$ & $7.61^{\circ}$ & $5.56^{\mathrm{b}}$ & $0.85^{\circ}$ & $6.42^{b}$ & $2.83^{4 b}$ \\
\hline & & 0.19 & 0.14 & 0.14 & 0.03 & 0.16 & 0.05 \\
\hline & & 13.18 & 7.52 & 4.81 & 0.76 & 5.66 & 2.79 \\
\hline & & 0.27 & 0.18 & 0.41 & 0.03 & 0.16 & 0.12 \\
\hline
\end{tabular}

*TS = Total solids; SNF = Solids-not-tat

${ }^{\text {abe }}$ Means in a colume with different superseripts differ significantly(Pev.05).

The mean total solids (TS) showed consistent increase from carly $(11.87 \%)$ to late $(1+.03 \%)$ lactation. The mean vatue for mid-factation was $13.56 \%$. The differences in the lactation periods were significant ( $\mathrm{p}<0,05$ ) The total solids increased linearly from 12.51 to 14.53 percent in weeks 8 to 12 respectively, decining to 13.83 pervent in week 16 before incrcasing again to is.50 percent in the jast week of lackition. The overall mean value $\left(13.18+0.27^{\circ}\right.$ of is less than the values reported ior the West African Dwari
(18.30\%) and Red Sokoto (15.83\%) goat milk $(\mathrm{Mba}$ et of; 1975). The present TS value is however, uuch higher than the values of $10.60 \%$ reportod for saranen (Pilla et al., 1980) and $12.8 \%$ reportod for stancs and Alphine goat milk (Varma and Cilawlis, 1984)

The mean butterfat coment $(\%)$ of milk were $6.81+0.23$ in carly. $8.18 \%+34$ in mid and $7.61+0.14^{4}=$ in lente factation wilh an overall mean valuc of $7.5 \%+0.18 \%$ in an earlier study Mba ef al (1975) ncerced comparable values of 
$6.70,7.78$ and 7.26 butterfat in early, mid and late lactation, respectively in the West African Dwarf goat milk. The butterfat concentration in these two studies exhibited similar trend: rapid increase from carly to mid-lactation and slight decline in late lactation. This observation is, however, at variance with the results of Flamant and Morand-Fichr (1982) which showod that butterfat was highest in early lactation, decreased quickly and increased again in late lactation. The differences could probably be due to breed effect, physiological condition of the animal, feed composition, methods and efficiency of chemical analysis. High concentrate low roughage diets have been reported to depress the butterfat level of milk (Kay, 1966; storry, 1970; Rook, 1976).

The present SNF values (Table 3) followed similar trend as those of total solids. The SNF content increased with advancing lactation attaining peak $(7.13 \%)$ in the $19^{\text {th }}$ week. However, the overall mean value $(5.66+0.16 \%)$ is lesser than those reported in the literature (Mba et al, 1975; Quresh et al., 1981; Varma and Chawla, 1984; Boros et al., 1985). Breed differences in the SNF content of goat milk have been confirmed (Parkash and Jenness, 1968). Protein concentration in milk constitutes the main differences in SNF content. The mean milk protein content (Table 3 ) in carly, mid and late lactation were $4.41 \pm 0.14,4.61 \pm 0.16$ and $5.56 \pm 14 \%$, respectively. The overall mean value $(4.81+0.15 \%)$ is comparable to the reported values of $4.60 \%$ for Red Sokoto and $4.71 \%$ for the West African Dwarf goat milk (Mba et al., 1975). The value is however, higher than those reported for goats elsewhere (Pilla $e t$ al., 1980; Quresh et al., 1981; Boros et al; 1985). The ash percentage representing the mineral content of the milk followed similar pattern as the TS throughout the lactation. Ash content was significantly influenced by lactation period. Total mineral content of milk attained maximum in late lactation which is contrary to the finding of Polychroniadou and Vafopoulou (1985) who reported maximum ash content in mid lactation among Greek sheep breeds. The overall ash valuc $(0.76+0.03 \%)$ is comparable to those (0.72 and $0.77 \%$ ) reported for Russian goats and sheep, respectively (Boros et al: 1975) and $0.78 \%$ for Indian goats (Quresh et al; 1981) The energy values (Table 3) were affected by stage of lactation, increasing significantly $(\mathrm{P}<0,05)$ in mid lactation before declining in late lactation. The mean values for early and late lactation were similar $(\mathrm{p}>0.05)$. The correlation coefficients( $r$ ) between fat and protein $(r=$ $0.158)$, fat and energy $(r=0.998)$, SNF and protein $(r=0.959)$ and SNF and energy $(r=$ 0.279 ) were computed. The correlations between fat and encrgy as well as SNF and protein were positive and significant $(P<0.01)$. Highly significant correlation between fat and energy in the milk of the west African Dwarf goat and the Red Sokoto goat has been reported (Mba et al., 1975).

\section{Conclusion}

In conclusion, the data suggests that the milk of sahelian goats have constituents comparable to those of their counter parts elsewhere in Nigeria and other countries. The constituents of colostrum tended to decline progressively from the $1^{n}$ to the $6^{\text {th }}$ day after kidding and approached values of mature milk on the $7^{\text {th }}$ day. Mature milk constituents were significantly influenced by stage of lactation.

\section{Acknowledgement.}

The authors wish to express their gratitude to Messrs Tami Mshelia and Albert Ugorji for their technical assistance.

\section{References}

Akinsoyinu, A.O. 1981. The composition of milk of the Fricsian cattle imported into Nigeria. J.Sci. Food Agric. 32: 863-867

Akinsoyinu, A.O. and Akinyele, L.O. 1979. Major elements in the Milk of the West African Dwarl goats as affected by the stage of lactation. $J$. Dainy Res. 46.427-431.

A. O.A.C 1990. Official Methods of Analysis. $15^{\text {th }}$ Edition. Acraciation of official Analytical Chemis/s, Washungton, D.C 


\section{Ibeawuchi, Ahamefule and Ringim}

Belanger, J. 1975. Raising milk goats the modern wry. Garden way pub]. Co. Vermont, U.S.A.

Boros, V; Kroal, Z and Stavonkova, E. 1985. Changes in the composition of goat and sheep mill in the course of lactation. Anim. Breeding. Abstr. 53:11

Devendra, C. and Burns, M. 1970 . Goat prodaction in the tropics. Commonwealth Agric. Bureatx, farnham Royal, U.K.

Flamant, J.C. and Morand-Fehr, O. 1982. Milk production in sheep and soats. In: Worid Animal Science sheep and Goat production. Edited by 1.E. Coop. Elserier Scientific Publ. Coy. N.Y. PP 275-295.

F.O.S 1996. Anmual Abstract of statistics. Federal office of statistics Lapos. Statistical information for the nation $1996 \mathrm{edn}$. PP. 249-256.

French, M.H. 1970. Observation on the Goat. F.A.O studies, No . 80 of F.A.O. Rome pp 294-129

Haenlein, G. F, W, 1981. Dain goat industry of the Unitod states. J. Dairy Sci, 64:1288-1304.

James, 1.J. and Osinowo, O.A. 2002. Changes in udder dimensions of West Afritan Dwarf, Red Sokoto and sahel goats during pregnancy and their relationship with panial daily milk yield. NSAP conf. Proc. March 17-21, 2002, FUTA, Nigeria. 27:39-42

Jenness, R. 1980. Composition and characteristics of goat milk; Review 1968-1979. J. Dainy Sci. 63: $1605-1630$.

Jenness, R. and Sloan, R.E. 1970. The composition of milks of various species. A review, Dairy Sef. Abstr. 32:599-612.

Kay, M, 1966. High concentrate low fibre diets for dairy cows. Feed formm I(1):2-4

M.A. F.F. 1977. Energy allowances and feeding systems for ruminants. Tech, Bull. 33. Ministry of Agric, Fisheries and food, I.ondon

Malau-Aduli, A.E.O. and Anlade, Y.R. 206)1. Variations and correlations in the composition of bovine, ovine and caprine mulk. IS.tP

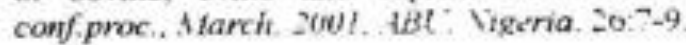

Malua-Aduli, B.S., Eduvie, L.O., Lakpini. C.A. M. and Malua-Aduli, A.E.O. 2002. Effect of supplementation on the milk yild and composition of Red sokoto doe. NSAP conf. Proc., March 17-21, 2002, FUTA, Nigeria. 27:353-355.

Mba, A.U., Boyo, B.S and Oyenuga, V.A 1975. Studies on the milk composition of West African Dwarf Red Sokoto and Saanen goats at different stages of lactation. J. Dairy res. 42 : 217-226.

Nuru, S 1990. Research achievements in dairy production. Paper presented at the National Dairy seminar, Hill station Hotel, Jos, Nigeria, 9-10 August, 1990.

Parkash, S. and Jennes, R. 1968. The composition and Characteristics of goats milk A Review. Dairy Sci. Abstr. 20.67-87

Pearsons, D. 1977. The chemical Analysis of foods chemical Publ. Coy. Inc, N.Y.

Pilla, A,M., Delli, A.S., Scardella, P., Taibi, L and Tarka, L 1980. Milk production by Gargano, maltese and Sannen goats. Annalida Institution sperimentale peria Zoolecnica 12(2) 143-150

Polychroniadou, A. and Vafopoulou, A. 1985. Variation of major mineral constituents of ewe milk during lactation. J. Dainy Sci 68:147-150

Quresh, H.A.., Desh Pande, K.S and Bondett, S. 1981. Study of chemical composition of goat milk. Indian vet. J. 58(3): 212-214.

Rook, J.A. F. 1976. Nutritional influences on milk quality. In: Principles of cattle production. Editors H. Swan and W.H. Broster, Butterworths London PP 221-236.

Steel, R. G.D. and Torrie, J.H. 1980. Principles and procedures of statistics. MoGraw-Hill kongasha Ltd., Tokyo, Japan

Storry, J.E 1970. Reviews of the Progress of dairy Science. Section A Physiology. Ruminant metabolism in relation to the synthesis and secretion of milk fat. $J$. dairy Res. 37:139-164.

Varma, N.K. and chawla, Dos. 1984. Variation of milk composition in dairy goats. Indian J. Anim. Sci. 5(6): 539-543. 